\title{
COVID-19 and Stress: A Young Male Presenting with Central Cyanosis, Dark Urine, Oliguria, Jaundice and Anemia due to Methemoglobinemia as a result of Suicidal Naphthalene Mothball Poisoning Recovered with Exchange Transfusion
}

\begin{abstract}
Khin Phyu Pyar ${ }^{*}$, Soe Win Hlaing ${ }^{2}$, Aung Aung ${ }^{3}$, Zar Ni Htet Aung², Nyan Lin Maung², Kaung Myat', Kyaw Thuyein Lwin ${ }^{4}$, Lay Maung Maung $^{5}$, Ye Min Hein ${ }^{5}$, Lynn Htet Aung, Chan Pyae Aung, Moe Tun Zaw ${ }^{5}$, Myo Maung Maung ${ }^{5}$, Aung Phyoe Kyaw ${ }^{2}$, Thurein Win ${ }^{2}$, Kyaw Zay Ya ${ }^{3}$, Myo Thant Kyaw 6 , Zaw Lin Oo ${ }^{6}$, Zay Phyo Aung ${ }^{6}$ \& Aung Kyaw Thu ${ }^{6}$
\end{abstract}

${ }^{1}$ Professor and Head/Senior Consultant Physician, Department of Medicine/ Department of Nephrology, Defence Services Medical Academy/ No.(1) Defence Services General Hospital (1000-Bedded).

${ }^{2}$ Senior Consultant Physician, No. (1) Defence Services General Hospital (1000-Bedded).

${ }^{3}$ Consultant Physician and Haematologist, No. (1) Defence Services General Hospital (1000-Bedded).

${ }^{4}$ Consultant Nephrologist, No. (1) Defence Services General Hospital (1000-Bedded).

${ }^{5}$ Nephrology Fellow, No. (1) Defence Services General Hospital (1000-Bedded).

${ }^{6}$ Assistant Lecturer / Consultant physician, Defence Services Medical Academy.

*Corresponding author: Khin Phyu Pyar, Department of Medicine/ Department of Nephrology, Defence Services Medical Academy/ No.(1) Defence Services General Hospital.

Received date: November 26, 2021; Accepted date: December 27, 2021; Published date: January 07, 2022

Citation: Khin P. Pyar, Soe W. Hlaing, A. Aung, Zar N. H. Aung, Nyan L. Maung, et al. (2022). The Effective Management and Outcome of Hand Burns. J Clinical Research and Reports, 10(2); DOI:10.31579/2690-1919/217

Copyright: (C) 2022, Khin Phyu Pyar. This is an open access article distributed under the Creative Commons Attribution License, which permits unrestricted use, distribution, and reproduction in any medium, provided the original work is properly cited.

\section{Abstract \\ Case Summary \\ A young man presented with abdominal pain and vomiting after eating Naphthalene Mothball. He had dyspnea, central cyanosis $\left(\mathrm{SaO}_{2}\right.$ on air was $67 \%$ on air), marked pallor, deep jaundice and dehydration. His urine color was black; and, his plasma in clotted blood sample was brownish. He was treated as methemoglobinemia due to suicidal Naphthalene Mothball poisoning with fluid and electrolyte replacement, ascorbic acid, $\mathrm{N}$-acetylcystine and exchange transfusion twice with four units of whole blood. Dramatic improvement in central cyanosis immediately following exchange transfusion. Psychiatric consultation and counselling were done; he admitted the main reason for committing suicide was socioeconomic stress due to COVID-19. \\ Key words: COVID-19; stress reaction; central cyanosis; dark urine; oliguria; jaundice; anaemia; methemoglobinemia; suicide; naphthalene mothball poisoning; exchange transfusion}

\section{Introduction}

In COVID-19 pandemic, the incidence of mental health problems are increasing; anxiety, depression, alcoholism, suicide and stress disorder (Shevlin et al., 2020) (Stevenson \& Wakefield, 2021) (Sahimi et al., n.d.) (Ueda et al., 2020). The impact of the COVID-19 pandemic on stress, mental health and coping behaviour were found to be changing (Voltmer et al., 2021).
Naphthalene (mothball) is a commonly used deodorizer. Naphthalene poisoning is a rare form of toxicity that may occur after ingestion, inhalation, or dermal exposure to naphthalene-containing compounds such as mothballs. Poisoning may present with acute manifestation or chronic form depending on extent of poisoning. It is relatively common in children due to accidental poisoning (Sarangi et al., 2016). Even neonates may have poisoned due to inhalation from mother. Severe haemolysis from naphthalene poisoning occurs particularly in patients with G6PD deficiency, who have a low tolerance to oxidative stress. 
Renal failure as a complication of naphthalene-induced haemolysis and haemoglobinuria has been reported. Early recognition of methemoglobinemia following anesthetic drugs is important in operating theater and recovery room (Sharma \& Haber, 2002) (Cefalu et al., 2020). In mild cases, $\mathrm{SaO}_{2}$ may be normal (Uthuman et al., 2019).

Extremely rare form of poisoning was reported in patients with end stage renal disease on maintenance hemodialysis due to contamination of dialysis fluid with $\mathrm{H}_{2} \mathrm{O}_{2}$ in dialysis water (Newbigging et al., 2009).

Mode of entry of naphthalene, age of patients and their underlying medical diseases in several case reports were interesting: (1) the youngest one was neonate due to inhalation or ingestion of mother during gestation (Molloy et al., 2004) (Sahni et al., 2019); (2) mother and baby due to ingestion (Molloy et al., 2004); (3) two year old baby presented with metabolic acidosis due to ingestion (Annamalai et al., 2012); (4) 21 month old baby with G6PD deficiency due to ingestion (Dela Cruz et al., 2019); (5) two patients with autism due to ingestion (Volney et al., 2018) (Kapoor et al., 2014); (6) a case of carcinoma of stomach following benzocaine spray (Lockhart \& Ong, 2018); (7) severe COVID-19 infection (Faisal et al., 2020) (Naymagon et al., 2020); (8) patients requiring renal replacement therapy (Kundra et al., 2015) (Deo et al., 2016).

\section{Case Presentation}

A 21-year-old male was brought to hospital last month because he had abdominal pain and vomiting after eating Naphthalene Moth ball. He was drowsy, dehydrated, dyspnoeic, respiratory rate $32 / \mathrm{min}, \mathrm{SaO}_{2}$ on air was $67 \%$ on air, it increased to only $70 \%$ with $10 \mathrm{~L}$ of oxygen (Double Flow Meter). Blood pressure was $160 / 90 \mathrm{mmHg}$, pulse rate 124 / minutes. He had marked pallor and was deeply jaundiced. Abdomen was soft and nontender. Urine color was black.

Thorough history taking revealed that he had eaten three Naphthalene Moth ball (25g each) per day for two days (total 6 ball) with the intention to die 5 days ago. He felt nothing till 24 hours after ingestion of 3 balls; then, he took 3 more balls. On the next day, he had vague abdominal pain, nausea and vomiting. He also noticed that his urine color changed to black and oliguria 48 hours later. And his friends took him to hospital. First, his urgent blood tests for full blood count and electrolyte were refused from lab as they thought it was the hemolyzed blood due to wrong storage as the color of plasma was chocolate brown. After discussion with biochemists, they performed the tests. He had severe anaemia ( $\mathrm{Hb} 6.2 \mathrm{~g} \%$;
MCV $93 \mu \mathrm{m}$, MCH 31 pg, MCHC 33.4 g/dl) with low PCV (Hct 18.5), neutrophil leucocytosis (Total WBC $22.8 \times 10^{9} / \mathrm{L}, \mathrm{N} 67.5 \%$, L $27.4 \%$, M $5.1 \%$ and low normal platelet count $\left(179 \times 10^{9} / \mathrm{L}\right)$. Severe anemia was due to hemolysis as the patient had elevated LDH and retic count Peripheral blood film examination showed changes in RBC series like numerous hemighost cells, irregularly contracted cells, bite cells, spherocyte and polychromatic cells indicating evidence for oxidative hemolysis. Figure (1) Reticulocyte count was raised 5 times normal (8 $\%)$.

He had oliguria and raised serum creatinine nearly three times normal (Urea $110.5 \mathrm{mg} / \mathrm{dl}$; Crearinine $2.82 \mathrm{mg} / \mathrm{dl}$ ); serum sodium was $131 \mathrm{meq} / \mathrm{l}$, potassium was $4.12 \mathrm{meq} / \mathrm{l}$ and, chloride was $94.1 \mathrm{meq} / \mathrm{l}$. Chest radiograph was normal. His nasopharyngeal swab PCR was negative. His ALT was normal- 38.9 U/L (0-40) and AST was five times normal- 196.3 U/L (037). Prothrombin time was $17.9(10-14)$ and INR was 1.45 . Although methemoglobin level in blood, and the discrepancy in arterial oxygen level from $\mathrm{ABG}$ and $\mathrm{SaO}_{2}$ percent in pulse oximeter were not measured, he was treated as a case of methemoglobinemia due to suicidal Naphthalene Mothball poisoning.

He was given high concentration oxygen, fluid and electrolytes replacement, $\mathrm{N}$ acetyl cystine, ascorbic acid, Ceftriaxone $1 \mathrm{G}, 8.4 \% \mathrm{Na}$ $\mathrm{HCO}_{3}$, Dexamethasone, and anti-emetics. Hematologist decided to do urgent exchange transfusion. Nephrologist suggested fluid and electrolytes replacement to combat dehydration which caused acute kidney injury. The pre-procedure workup was done including $\mathrm{ABO}$ and Rh typing, antibody screening and matching.

After doing one unit of exchange transfusion, his $\mathrm{SaO}_{2}$ improved at a drastic rate $68 \%$ (with oxygen double source with high flow mask) to $70 \%$ with CPAP. Then, $\mathrm{SaO}_{2}$ rose to $80 \%$ with CPAP after two units of exchange transfusion; clinically, the degree of central cyanosis was much better and patient became more alert. Second exchange transfusion was done 24 hour later; $\mathrm{SaO}_{2}$ improved to $90 \%$ after third unit of exchange and $94 \%$ following fourth unit of exchange transfusion. $\mathrm{His}^{\mathrm{SaO}_{2}}$ became gradually back to normal with oxygen $2 \mathrm{~L} / \mathrm{min}$ on the next day. Two days after second exchange, his $\mathrm{SaO}_{2}$ was $99 \%$ on air; and, urine color was nearly normal. Urine output improved too. Anemia was improving and jaundice was decreasing. The plasma of clotted blood sample became clearer by day 3. His G6PD assay was normal. He admitted that he did suicide because of economic reasons; and, psychiatric consultation was done.

\begin{tabular}{|l|l|l|l|l|l|l|}
\hline & $\begin{array}{l}\text { Arrival } \\
\text { Day 0 }\end{array}$ & Day 1 & Day 3 & Day 4 & Day 5 & Day 7 \\
\hline $\begin{array}{l}\text { General } \\
\text { condition }\end{array}$ & drowsy & drowsy & alert & Alert & alert & alert \\
\hline SaO2 & $\begin{array}{l}67 \% \text { on air } \\
70 \% \text { DFM } \\
80 \% \text { CPAP }\end{array}$ & $85 \%$ CPAP & $94 \%$ DFM & $98 \%$ on air & $99 \%$ on air & $99 \%$ on air \\
\hline Anemia & ++ & ++ & ++ & + & & \\
\hline Jaundice & ++ & ++ & + & + & & \\
\hline Blood pressure & $160 / 90$ & $135 / 75$ & $120 / 70$ & $120 / 80$ & $120 / 80$ & $130 / 80$ \\
\hline $\begin{array}{l}\text { Exchange } \\
\text { transfusion }\end{array}$ & 2 units & 2 units & 2 units & & & \\
\hline Urine colour & black & black & brown & Normal & normal & normal \\
\hline Urine output & 50 & 1500 & 1500 & 3000 & 3200 & 6500 \\
\hline
\end{tabular}

Table 1: Clinical progress 


\begin{tabular}{|c|c|c|c|c|c|c|c|c|c|c|c|}
\hline Date & Day 0 & $\begin{array}{l}\text { Day } \\
1 \text { am }\end{array}$ & $\begin{array}{l}\text { Day } \\
1 \\
\text { pm }\end{array}$ & Day 2 & $\begin{array}{l}\text { Day } \\
4\end{array}$ & $\begin{array}{l}\text { Day } \\
5\end{array}$ & $\begin{array}{l}\text { Day } \\
7\end{array}$ & $\begin{array}{l}\text { Day } \\
11\end{array}$ & $\begin{array}{l}\text { Day } \\
16\end{array}$ & $\begin{array}{l}\text { Day } \\
21\end{array}$ & $\begin{array}{l}\text { Day } \\
28\end{array}$ \\
\hline Hb (11-16.5) & 6.5 & 6.2 & 6.1 & 6.7 & 8.9 & 9.3 & & 9.3 & 10.4 & 10.6 & 11.5 \\
\hline $\begin{array}{l}\text { MCV (80-97) } \\
\text { um }^{3}\end{array}$ & 92 & 93 & 93 & 98 & 90 & 94 & & 97 & 96 & 98 & 86 \\
\hline $\begin{array}{l}\text { MCH (26.5- } \\
33.5) \mathrm{pg}\end{array}$ & 34.4 & 31 & 31.8 & 28.7 & 26.7 & 27.9 & & 27.9 & 28 & 27.4 & 28.3 \\
\hline $\begin{array}{l}\text { MCHC (31.5- } \\
35) \mathrm{g} / \mathrm{dl}\end{array}$ & 37.6 & 33.4 & 34.2 & 29.3 & 29.6 & 29.7 & & 28.8 & 29.2 & 27.9 & 32.7 \\
\hline $\begin{array}{l}\text { HCT }(35-50) \\
\text { L\% }\end{array}$ & 17.2 & 18.5 & 17.8 & 22.8 & 30.2 & 31.4 & & 32.4 & 35.7 & 38 & 35.2 \\
\hline $\begin{array}{l}\text { TWBC } 3.5- \\
10 \times 10^{3} \mathrm{~mm}^{3}\end{array}$ & 22.9 & 22.8 & 22.3 & 10.7 & 11.5 & 13.3 & & 12.5 & 16.7 & 6.4 & 6.09 \\
\hline $\begin{array}{l}\text { Neutrophil } \\
(1.2-6.5) \quad(43- \\
76)\end{array}$ & $\begin{array}{l}16.3 \\
(70.8 \\
\%) \\
\end{array}$ & $\begin{array}{l}15.5 \\
(67.5 \\
\%) \\
\end{array}$ & $\begin{array}{l}15.1 \\
(67.3 \\
\%) \\
\end{array}$ & $\begin{array}{l}8.7 \\
(80 \%)\end{array}$ & $\begin{array}{l}10.3 \\
(88.1 \\
\%) \\
\end{array}$ & $\begin{array}{l}11.8 \\
(88.2 \\
\%) \\
\end{array}$ & & $\begin{array}{l}11.6 \\
(91.2 \\
) \\
\end{array}$ & $\begin{array}{l}15.5 \\
(92.4 \\
\%) \\
\end{array}$ & $\begin{array}{l}4.3 \\
(64.7 \\
\%) \\
\end{array}$ & $\begin{array}{l}2.76 \\
(45.4 \\
\%) \\
\end{array}$ \\
\hline $\begin{array}{l}\text { Lymphocytes } \\
(1.2-3.2)(17- \\
48)\end{array}$ & $\begin{array}{l}5.5 \\
(24.2 \\
\%) \\
\end{array}$ & $\begin{array}{l}6.2 \\
(27.4 \\
\%) \\
\end{array}$ & $\begin{array}{l}6.2 \\
(27.9 \\
\%) \\
\end{array}$ & $\begin{array}{l}1.6 \\
(15 \%)\end{array}$ & $\begin{array}{l}0.9 \\
(8.5 \\
\%) \\
\end{array}$ & $\begin{array}{l}1.1 \\
(8.5 \\
\%) \\
\end{array}$ & & $\begin{array}{l}0.7 \\
(6.4 \\
\%) \\
\end{array}$ & $\begin{array}{l}0.9 \\
(5.4 \\
\%) \\
\end{array}$ & $\begin{array}{l}1.8 \\
29.4 \\
\%) \\
\end{array}$ & $\begin{array}{l}2.45 \\
(40.2 \\
\%) \\
\end{array}$ \\
\hline $\begin{array}{l}\text { Monocytes } \\
(0.3-0.8) \quad(4- \\
10)\end{array}$ & $\begin{array}{l}1.1 \\
(5 \%)\end{array}$ & $\begin{array}{l}1.1 \\
(5.1 \\
\%) \\
\end{array}$ & $\begin{array}{l}1 \\
(4.8 \\
\%) \\
\end{array}$ & $\begin{array}{l}0.4 \\
(4.5 \% \\
) \\
\end{array}$ & $\begin{array}{l}0.3 \\
(3.4 \\
\%) \\
\end{array}$ & $\begin{array}{l}0.4 \\
(3.3 \\
\%) \\
\end{array}$ & & $\begin{array}{l}0.2 \\
(2.4 \\
\%) \\
\end{array}$ & $\begin{array}{l}0.3 \\
(2.2 \\
\%) \\
\end{array}$ & $\begin{array}{l}0.3 \\
(5.9 \\
\%) \\
\end{array}$ & $\begin{array}{l}0.44 \\
(7.2 \\
\%) \\
\end{array}$ \\
\hline $\begin{array}{l}\text { Platelet (150- } \\
390)\end{array}$ & 182 & 179 & 164 & 138 & 123 & 221 & & & 362 & 290 & 184 \\
\hline $\begin{array}{l}\mathrm{Na}+(135-148 \\
\mathrm{mmol} / \mathrm{L})\end{array}$ & & 131 & & 129 & 129 & 131 & 137 & 140 & 137 & 142 & \\
\hline $\mathbf{K}+(3.5-5.3)$ & & 3.76 & & 3.7 & 3.78 & 3.96 & 3.7 & 4.12 & 4.13 & 3.91 & \\
\hline Cl- (96-106) & & 91.7 & & 93.3 & 95.8 & 93.4 & 99.7 & 97.4 & 96.3 & 97.4 & \\
\hline $\begin{array}{l}\text { Urea }(10-50 \\
\mathrm{mg} / \mathrm{dl})\end{array}$ & & 129.5 & & 136.7 & 52 & & 72.9 & 71.3 & 30.1 & 59.5 & 20.3 \\
\hline $\begin{array}{l}\text { Creatinine } \\
(0-1.3 \mathrm{mg} / \mathrm{dl}) \\
\end{array}$ & & 3.25 & & 3.32 & 2.4 & & 1.97 & 1.68 & 1.51 & 1.43 & 1.26 \\
\hline $\begin{array}{ll}\text { ALT } & (0-40 \\
\text { U/L }) & \\
\end{array}$ & & 38.9 & & 37 & & & & & & & 80.2 \\
\hline $\begin{array}{ll}\text { AST } & (0- \\
37 \mathrm{U} / 1) & \\
\end{array}$ & & 196.3 & & 37.5 & & & & & & & 54 \\
\hline $\begin{array}{l}\text { Alkaline } \\
\text { Phosphate } \\
\text { (40-106U/L0 }\end{array}$ & & & & & & & & & & & 123 \\
\hline $\begin{array}{l}\text { LDH (135- } \\
225 \text { U/L) }\end{array}$ & & & & 3009 & & & & & & & 248 \\
\hline $\begin{array}{l}\text { Amylase } \quad(0- \\
82 \text { U/L) }\end{array}$ & & & & 159 & & & & & & & \\
\hline $\begin{array}{l}\text { Ferritin (13- } \\
400 \mathrm{ng} / \mathrm{ml})\end{array}$ & & & & 2000 & & & & & & & \\
\hline G6PD & & & & & & & & & $\begin{array}{l}\text { Not } \\
\text { Defic } \\
\text { ient } \\
\end{array}$ & & \\
\hline PT $(10-14) \mathrm{s}$ & 17.9 & & & & & & & & & & 11.6 \\
\hline INR & 1.45 & & & & & & & & & & 0.88 \\
\hline Serology & NR & $\begin{array}{l}\text { Malar } \\
\text { ia } \\
\text { ICT } \\
\end{array}$ & Neg: & & & & & & & & \\
\hline
\end{tabular}




\section{Discussion}

Naphthalene mothballs are commonly used in households; it is very uncommon agent of poisoning worldwide. Severe haemolysis from naphthalene poisoning is rare unless there is no G6PD deficiency. Toxic manifestations of naphthalene may be due to enhanced production of free oxygen radicals, resulting in lipid peroxidation and deoxyribonucleic acid damage. The patient did not have G6PD deficiency; however, he developed methemoglobinemia, central cyanosis, acute kidney injury and liver toxicity. Acute kidney injury was owing to naphthalene-induced haemolysis, haemoglobinuria, pigment nephropathy and acute tubular necrosis, requiring renal replacement therapy (Deo et al., 2016).

The patient had all manifestations of naphthalene poisoning which was rarely reported before: drowsiness, confusion, behavioral changes, fits, ocular palsy; neurological involvement; nausea, vomiting and abdominal pain; gastrointestinal involvement, jaundice and raised liver enzymes; hepatic involvement, black urine and acute kidney injury; renal involvement, anemia, intravascular hemolysis and methemoglobinemia; hematological involvement, and, cyanosis, dyspnoea and reduced $\mathrm{SaO}_{2}$; respiratory system involvement.

In this patient, though he had dyspnoea, central cyanosis and low $\mathrm{SaO}_{2}$ on air, there was no clinical clues from examination of heart and lungs: clear lung field on auscultation and chest x-ray, normal blood pressure with normal cardiac examination. This peculiar finding, cyanosis with normal heart and lung, favored the diagnosis of methemoglobinemia. Clinical awareness is important to get early diagnosis and treatment. Thus, it is the good case to learn. The differential diagnosis of methemoglobinemia includes cyanotic congenital heart disease and sulfhemoglobinemia. The potassium cyanide test can distinguish between methemoglobin and sulfhemoglobin. But as the cause was already known, it was not required.

Methemoglobinemia and carbon monoxide poisoning are potentially lifethreatening conditions that can present with nonspecific clinical features; thus, exact diagnosis can be down with modern blood gas analyzers which measure carboxyhemoglobin $(\mathrm{COHb})$ and methemoglobin $(\mathrm{MetHb})$ levels. However, both are treatable with antidotes of methylene blue and oxygen (Shelton et al., 2020).
In this case, the technician noticed brownish plasma in clotted blood and informed the clinician for possible causes like over left specimen or intravascular hemolysis. This point was particularly imported in resource limited area where ABG or methemoglobin level was not easily available. Both the treating physician on call, the phlebotomist and lab technician had awareness of the color of plasma on clotted venous blood sample which turned brownish because of severe intravascular hemolysis in this case. Another important clue for methemoglobinemia is that if the color of the arterial blood changes to dark brown with normal $\mathrm{PaO}_{2}$ result. In this patient $\mathrm{ABG}$ and Coomb's test was not done; and, reagent for bilirubin was also in shortage. In this patient, getting early diagnosis was based on team collaboration between medicine on call team and laboratory team, highlighting the importance of intradepartmental collaboration.

Although the concentration of methemoglobin in the blood was not measured, it was above $1.5 \%$ if the patient had cyanosis. Methemoglobin is the oxidized form of hemoglobin, which does not bind oxygen and increases the affinity of oxygen for the partially oxidized portion of hemoglobin. Methemoglobinemia is fatal if not treated timely. Ascorbic acid acts as a free radical scavenger and hence may be useful in this situation.

Treatment includes oxygen, fluid therapy and observation. Acute kidney injury may need hemodialysis. Specific antidote, methylene blue, can be beneficial; however, caution must be taken as it can cause paradoxical methemoglobinemia in patients with G6PD deficiency. Vitamin C (ascorbic acid) and $\mathrm{N}$ acetyl cystine may be helpful. Exchange transfusion is life-saving in severe poisoning; report on good outcome with exchange transfusion if methemoglobinemia was refractory (Patnaik et al., 2014). The patient made dramatic improvement even after one unit of exchange transfusion. Therapeutic red cell exchange was one of treatment option (Khetarpal \& Kotwal, 2018) though some cases may improve with red cell transfusion (Volney et al., 2018).

\section{Conclusions:}

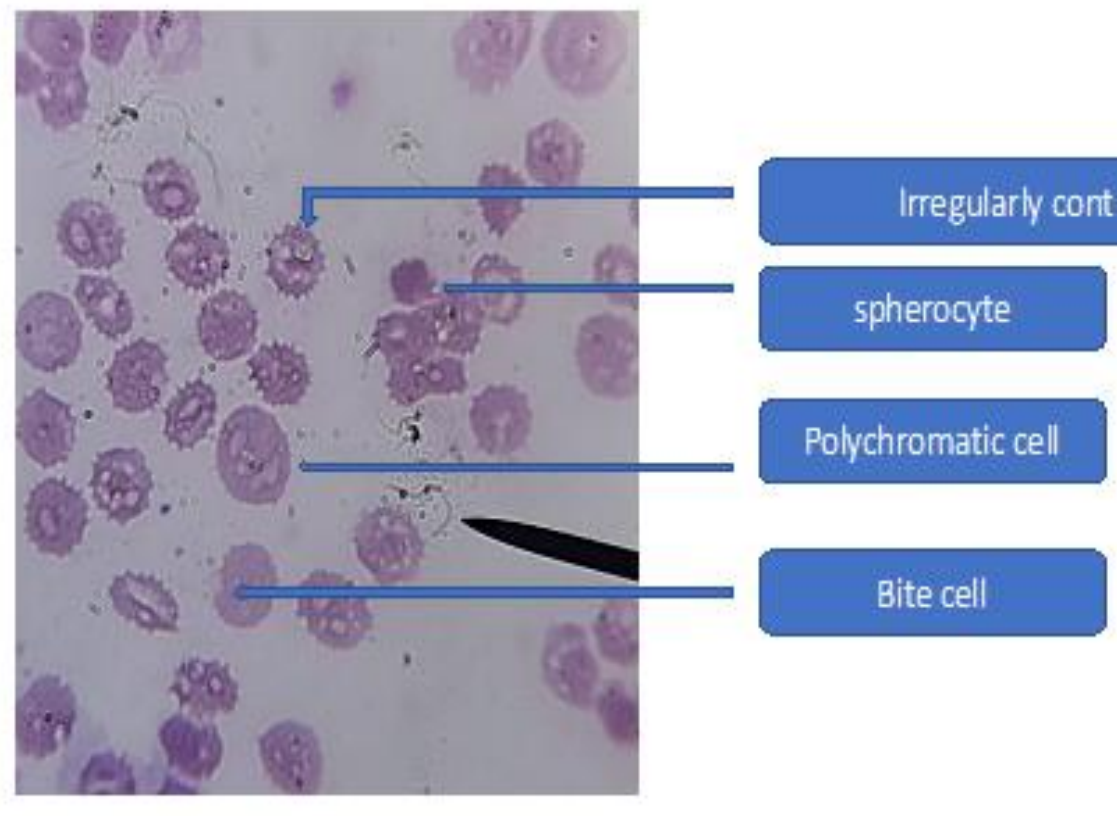

Figure 1: Blood film showing hemolysis (hemighost cell, bite cell, spherocyte, polychromatic cell) 
In COVID-19 era, psycho-social stress may lead to increase incidence of suicide; high index of suspicion on poisoning is important. Naphthalene toxicity is uncommon but fatal. It should be suspected in patients with black urine, nausea, vomiting and abdominal pain, combined with acute hemolytic anemia, methemoglobinemia, and acute kidney injury. Methemoglobinemia is a potentially severe disorder; it should be suspected in acutely dyspnoeic cyanotic patient with apparently normal lungs and heart in physical examination and chest radiograph. Treatment of naphthalene poisoning depends on severity of toxicity; supportive care, fluid therapy, respiratory support, ascorbic acid, methylene blue, and $\mathrm{N}$ acetyl cystine. Exchange transfusion is life-saving in severe naphthalene poisoning.

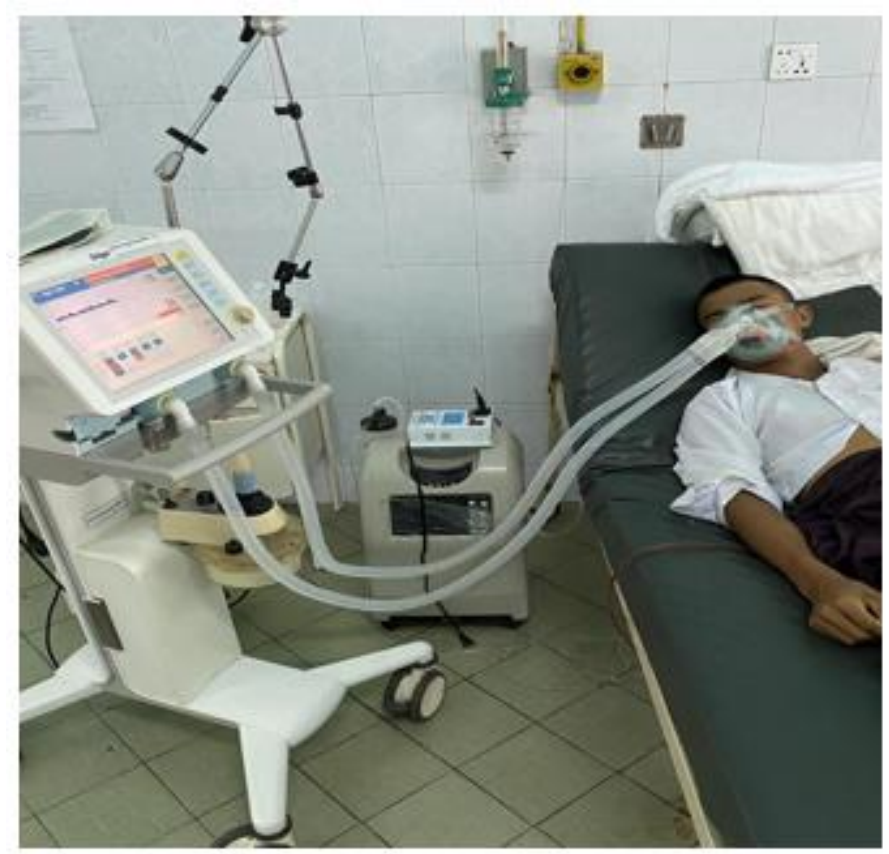

Figure 2: patient on CPAP

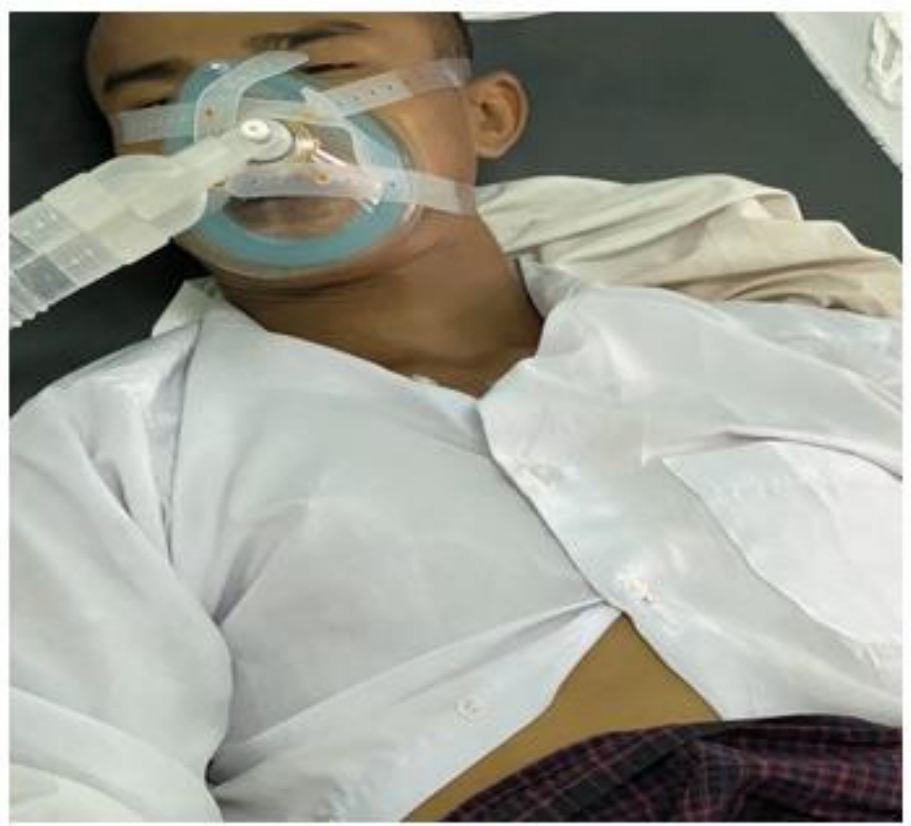

Figure 3: patient on CPAP, drowsy, jaundice and pale skin 


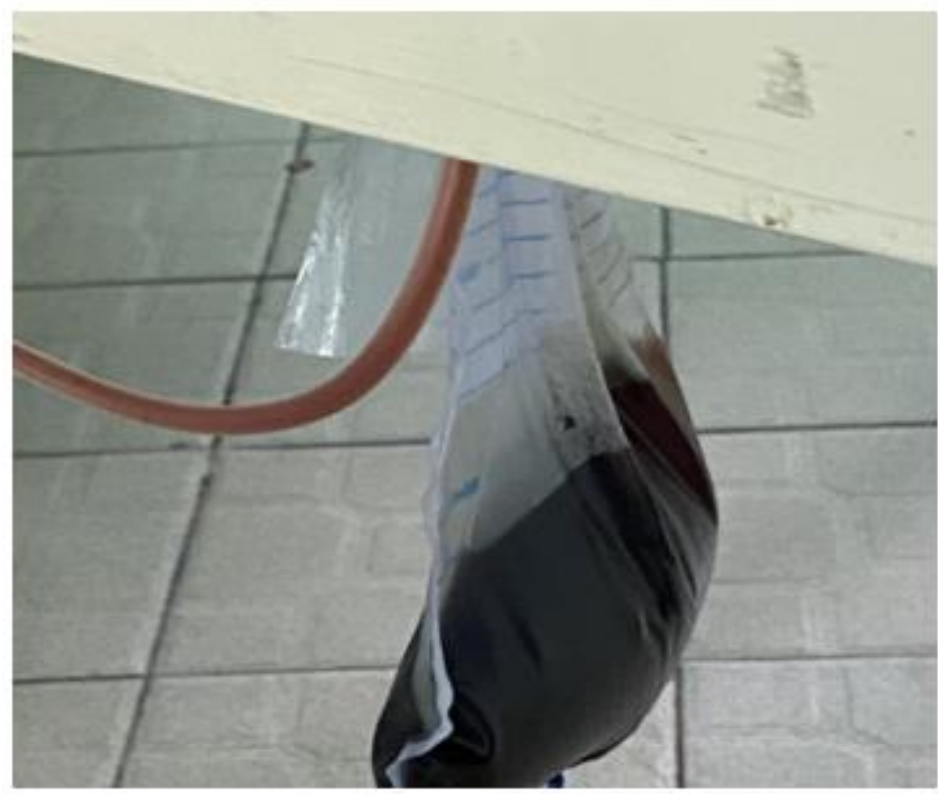

Figure 4: Black urine in urinary bag

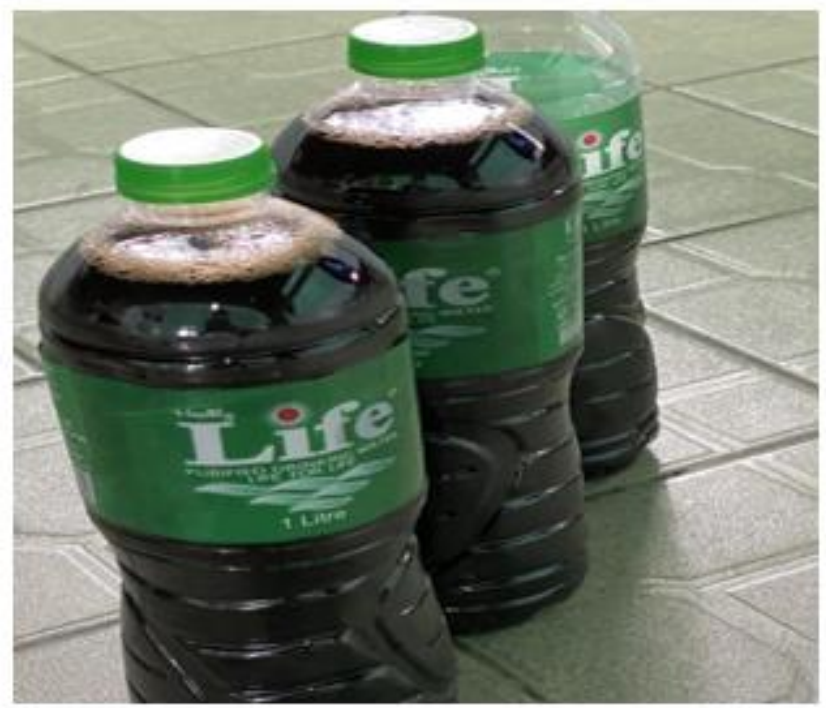

Figure 5: Serial urine collection

\section{Acknowledgements}

The authors would like to thank the patient for giving consent to this article. Also, to all doctors and nursing team for making great efforts in caring him. The authors acknowledged the following team; Professor Tin Moe Mya for laboratory support, Professor Myint Zaw, Professor Kyaw Zay Ya and Professor Ko Ko Lwin for administrative support.

\section{Declaration of conflict of interest}

The authors declared no potential conflicts of interests with respect to authorship and publication of this article.

\section{Ethical approval}

Our institution does not require ethical approval for reporting cases.

\section{Funding}

The authors received no financial support for publication of this article.

\section{Informed consent}

The informed consent for publication in this article was obtained from patient.

\section{References}

1. Annamalai, K. C., Shrikiran, A., Mundkur, S. C., \& Chaitanya Varma, P. (2012). Acute naphthalene toxicity presenting with metabolic acidosis: A rare complication. Journal of Acute Disease, 1(1), 75-76.

2. Cefalu, J. N., Joshi, T. V., Spalitta, M. J., Kadi, C. J., Diaz, J. H., Eskander, J. P., Cornett, E. M., \& Kaye, A. D. (2020). Methemoglobinemia in the Operating Room and Intensive Care Unit: Early Recognition, Pathophysiology, and Management. Advances in Therapy, 37(5), 1714-1723. Dela Cruz, M., Khalid, 
M. M., Mostafa, A., Ershad, M., Vearrier, D., \& McKeever, R. (2019). Hemolytic Crisis following Naphthalene Mothball Ingestion in a 21-Month-Old Patient with Glucose-6-Phosphate Dehydrogenase (G6PD) Deficiency. Case Reports in Pediatrics, 2019, 1092575.

3. Deo, P., Sahu, K. K., Dhibar, D. P., \& Varma, S. C. (2016). Naphthalene ball poisoning: A rare cause of acquired methaemoglobinaemia. BMJ Case Reports, 2016, bcr2016215102.

4. Faisal, H., Bloom, A., \& Gaber, A. O. (2020). Unexplained Methemoglobinemia in Coronavirus Disease 2019: A Case Report. A\&A Practice, 14(9), e01287-e01287. PubMed. Kapoor, R., Suresh, P., Barki, S., Mishra, M., \& Garg, M. K. (2014). Acute intravascular hemolysis and methemoglobinemia following naphthalene ball poisoning. Indian Journal of Hematology \& Blood Transfusion: An Official Journal of Indian Society of Hematology and Blood Transfusion, 30(Suppl 1), 317-319. PubMed.

5. Khetarpal, A., \& Kotwal, U. (2018). Role of Automated Therapeutic Red Cell Exchange in the Setting of Acute Methemoglobinemia: Our Experience. Indian Journal of Hematology \& Blood Transfusion: An Official Journal of Indian Society of Hematology and Blood Transfusion, 34(1), 143-145. PubMed.

6. Kundra, T. S., Bhutatani, V., Gupta, R., \& Kaur, P. (2015). Naphthalene Poisoning following Ingestion of Mothballs: A Case Report. Journal of Clinical and Diagnostic Research: JCDR, 9(8), UD01-UD2. PubMed.

7. Lockhart, V., \& Ong, M. (2018). 367 Red Blood Cell Exchange for Treatment of Acquired Methemoglobinemia in a Hospitalized Patient: A Case Report. American Journal of Clinical Pathology, 149(suppl_1), S159-S160.

8. Molloy, E. J., Doctor, B. A., Reed, M. D., \& Walsh, M. C. (2004). Perinatal Toxicity of Domestic Naphthalene Exposure. Journal of Perinatology, 24(12), 792-793.

9. Naymagon, L., Berwick, S., Kessler, A., Lancman, G., Gidwani, U., \& Troy, K. (2020). The emergence of methemoglobinemia amidst the COVID-19 pandemic. American Journal of Hematology, 95(8), E196-E197. PubMed.

10. Newbigging, N., Peel, W., Bell, E., \& Isles, C. (2009). Unexpected cyanosis in a haemodialysis patient-Did someone add hydrogen peroxide to the dialysis water? NDT Plus, 2(2), 158-160.

11. Patnaik, S., Natarajan, M. M., James, E. J., \& Ebenezer, K. (2014). Methylene blue unresponsive methemoglobinemia. Indian Journal of Critical Care Medicine: Peer-Reviewed,
Official Publication of Indian Society of Critical Care Medicine, 18(4), 253-255. PubMed.

12. Sahimi, H. M. S., Mohd Daud, T. I., Chan, L. F., Shah, S. A., Rahman, F. H. A., \& Nik Jaafar, N. R. (n.d.)

13. Sahni, M., Vibert, Y., Bhandari, V., \& Menkiti, O. (2019). Newborn Infant With Mothball Toxicity Due to Maternal Ingestion. Pediatrics, 143(6).

14. Sarangi, R., Pradhan, S., Prusty, B., \& Mahapatra, S. (2016). Acute intravascular hemolysis following accidental ingestion of naphthalene: A rare case report. In Journal of Applied Hematology (Vol. 7, Issue 2, pp. 76-78). Wolters Kluwer Medknow Publications.

15. Sharma, V. K., \& Haber, A. D. (2002). Acquired Methemoglobinemia: A Case Report of Benzocaine-Induced Methemoglobinemia and a Review of the Literature. Clinical Pulmonary Medicine, 9(1).

16. Shelton, D., Dashi, G., Cheung, M., \& Sindall, T. (2020). Case Report of Methemoglobinemia: An Illustration That It Is Time to Report all Results with Arterial and Venous Blood Gas Result Reporting. The Journal of Emergency Medicine, 58(2), e51-e54.

17. Shevlin, M., McBride, O., Murphy, J., Miller, J. G., Hartman, T. K., Levita, L., Mason, L., Martinez, A. P., McKay, R., Stocks, T. V. A., Bennett, K. M., Hyland, P., Karatzias, T., \& Bentall, R. P. (2020). Anxiety, depression, traumatic stress and COVID-19related anxiety in the UK general population during the COVID19 pandemic. BJPsych Open, 6(6), e125. Cambridge Core.

18. Stevenson, C., \& Wakefield, J. R. H. (2021). Financial distress and suicidal behaviour during COVID-19: Family identification attenuates the negative relationship between COVID-related financial distress and mental Ill-health. Journal of Health Psychology, 26(14), 2665-2675.

19. Ueda, M., Nordström, R., \& Matsubayashi, T. (2020). Suicide and mental health during the COVID-19 pandemic in Japan. MedRxiv, 2020.10.06.20207530.

20. Uthuman, A. A. A., Jayasinghe, C. S., \& Fernando, A. H. N. (2019). Acute intravascular hemolysis due to naphthalene toxicity: A case report. Journal of Medical Case Reports, 13(1), 91. $-\mathrm{x}$

21. Volney, G., Tatusov, M., Yen, A. C., \& Karamyan, N. (2018). Naphthalene Toxicity: Methemoglobinemia and Acute Intravascular Hemolysis. Cureus, 10(8), e3147-e3147. PubMed.

22. Voltmer, E., Köslich-Strumann, S., Walther, A., Kasem, M., Obst, K., \& Kötter, T. (2021). The impact of the COVID-19 pandemic on stress, mental health and coping behavior in German University students - a longitudinal study before and after the onset of the pandemic. BMC Public Health, 21(1), 1385.

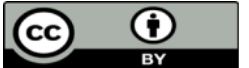

This work is licensed under Creative Commons Attribution 4.0 License

To Submit Your Article Click Here:

Submit Manuscript
Ready to submit your research? Choose Auctores and benefit from:

$>$ fast, convenient online submission

$>$ rigorous peer review by experienced research in your field

$>$ rapid publication on acceptance

$>$ authors retain copyrights

$>$ unique DOI for all articles

$>$ immediate, unrestricted online access

At Auctores, research is always in progress.

Learn more https://auctoresonline.org/journals/journal-of-clinical-researchand-reports 